\title{
PHYTOCHEMICALS SCREENING AND ACTIVITIES OF BINAHONG (ANREDERA CORDIFOLIA [TEN.] STEENIS) LEAVES AND BEETROOTS (BETA VULGARIS L.) IN INCREASING SWIMMING ENDURANCE IN MICE
}

\author{
MASNIAH*, JAMIDIN MANURUNG \\ Department of Pharmacy, Health Polytechnic Ministry of Health, Medan, North Sumatera, Indonesia. Email: mmasniah8@gmail.com \\ Received: 17 January 2018, Revised and Accepted: 14 March 2019
}

ABSTRACT

Objective: The aim of this research was to the identification of bioactive compounds and comparison of binahong (Anredera cordifolia [Ten.] Steenis) leaves and beetroots (Beta vulgaris L.) ethanol extract in swimming endurance activity in mice.

Methods: The type of research that has been carried out is experimental laboratory which includes identification of bioactive content quality and testing of swimming endurance effect by comparing the difference between before and after treatment by binahong leaves and beetroots ethanol extract.

Results: The results of bioactive compounds identification of binahong leaves and beetroots are alkaloids, glycosides, cyanogenic glycosides, flavonoids, and tannins. Steroid compounds are only found in binahong leaves. The results of swimming resistance are significantly different ( $<<0.05)$ in all groups. Animals group given $20 \%$ binahong leaves extract increased swimming resistance for 36,392 min, followed by caffeine for 33,440 minutes, then $10 \%$ binahong leaves extract for 29,142 min.

Conclusion: Binahong leaves and beetroots have almost the same bioactive content except in the steroid content. The binahong leaves swimming endurance activity is higher than the bit bulbs.

Keyword: Bioactive compound, Anredera cordifolia, Beta vulgaris, Swimming endurance.

(C) 2019 The Authors. Published by Innovare Academic Sciences Pvt Ltd. This is an open access article under the CC BY license (http://creativecommons. org/licenses/by/4. 0/) DOI: http://dx.doi.org/10.22159/ajpcr.2019.v12i4.31613

\section{INTRODUCTION}

Binahong (Anredera cordifolia) is a climbing succulent that is widely distributed in the southern parts of South America and China [1]. In the previous studies, A. cordifolia was reported to contain bioactive compounds that possess anti-inflammatory, anti-aging, antihypertension, vasodilatation, antibacterial, and antihyperlipidemic activities [2-7].

Beetroot (Beta vulgaris) belongs to the Chenopodiaceae family and is originally from temperate climate regions of Mediterranean, extensively cultivated in Europe, America, and many parts of India. Aqueous and ethanol extracts of beetroots have been reported to possess free radical scavenging activity, reducing the radical cations and Phase II enzyme-inducing activities in murine hepatoma cell in vitro study [8-10].

Binahong leaves and beetroot are often used as traditional medicines in Indonesia. Both of these plants are empirically used to increase the freshness and stamina of the body. Based on these activities, in this study, a swimming endurance test was carried out from test animals to prove the activity of both plants, and phytochemical screening was performed to determine the active content of the plants.

\section{MATERIALS AND METHODS}

\section{Materials}

The materials used are raw materials for binahong A. cordifolia (Ten.) Steenis leaves and beetroot (B. vulgaris L.) as samples (based on the results of the determination of the Herbarium Medanese), aquadest and ethanol $96 \%$ as solvents, caffeine as a comparison, Na CMC as a control as well as suspending agent, and analytical chemicals such as sodium chloride, $\mathrm{Pb}(\mathrm{II})$ acetate, iron(III)chloride, mercury(II)chloride, potassium iodide, iodine, naphthol, citric acid, bismuth nitrate, ether, chloroform, isopropanol, methanol, sodium sulfate anhydrous, ethyl acetate, magnesium powder, zinc powder, acid chloride, toluene, and concentrated sulfuric acid for identification of the contents of the active compounds.

\section{Preparation of ethanol extract}

Ethanol extract of binahong leaves (EEBL) and ethanol extract of beetroot tuber was made by maceration, using $96 \%$ ethanol. Weighed 10 parts of simplicia powder, add 75 parts of ethanol, cover tightly, let stand for 5 days protected from sunlight (during the stirring at least 3 times). After 5 days, the mixture is sealed, squeezed, and rinsed with pulp using a $25 \%$ residual solvent until 100 parts are obtained. Put it in a tightly closed container, let stand for 2 days in a dark place. Take clear solution, then macerate is evaporated by rotary evaporator until thick extract is obtained.

\section{Identification of alkaloids}

The ethanol extract $(500 \mathrm{mg}$ ) was divided into three test tubes. Afterward, the tubes were added with $1 \mathrm{~mL}$ of hydrochloric acid $2 \mathrm{~N}$ and $9 \mathrm{~mL}$ of water, respectively. Next, heated over a water bath for $2 \mathrm{~min}$, then cooled and strained. Then, added to each tube two drops of Meyer, Bouchardat, and Dragendorff reagents $[11,12]$.

\section{Identification of flavonoids}

The ethanol extract $(500 \mathrm{mg}$ ) was divided into two test tubes. After that, the tubes were added with $10 \mathrm{~mL}$ of methanol, respectively. Next, refluxed using a cooler for $10 \mathrm{~min}$. Filtered heat through multiple filter paper, diluted with $10 \mathrm{~mL}$ of distilled water. After cold, $5 \mathrm{~mL}$ of ether was added, stirring carefully, then let stand. The methanol layer is taken, evaporated at $40^{\circ} \mathrm{C}$ under pressure. The extract obtained was dissolved in $5 \mathrm{~mL}$ of ethyl acetate $[11,12]$. 
The extract in the first tube was evaporated to dryness, then dissolved in $2 \mathrm{~mL}$ of $96 \%$ ethanol, added $0.5 \mathrm{~g}$ of zinc powder and $2 \mathrm{~mL}$ of $2 \mathrm{~N}$ hydrochloric acid, left for $1 \mathrm{~min}$. Added 10 drops of concentrated hydrochloric acid, if within 2-5 min, there is an intense red color indicating the presence of flavonoids (glycoside-3-flavonol) [11,12].

The extract in the second tube was evaporated to dryness, dissolved in $1 \mathrm{~mL}$ of $96 \%$ ethanol, added $100 \mathrm{mg}$ of magnesium powder and 10 $\mathrm{mL}$ of concentrated $\mathrm{HCl}$, if red-orange was formed until the red-purple color indicated the presence of flavonoids. If orange yellow is formed, indicates the presence of flavones and chalcons $[11,12]$.

\section{Identification of glycosides}

The ethanol extract $(3 \mathrm{~g})$ was put into the Erlenmeyer, then added $30 \mathrm{~mL}$ of the mixture of $90 \%$ ethanol (7:3), concentrated sulfuric acid was added until the $\mathrm{pH}$ of solution 2 was obtained, then refluxed using a ball cooler for $10 \mathrm{~min}$, then cooled, and then filtered. After that, $20 \mathrm{~mL}$ of filtrate was taken and then $25 \mathrm{~mL}$ of water and $25 \mathrm{~mL}$ of lead (II) acetate $0.4 \mathrm{M}$ were added. Next, shaked and left for $5 \mathrm{~min}$, then filtered. The filtrate was extracted 3 times with $20 \mathrm{~mL}$ of a solvent mixture of chloroform: isopropanol (3:2) and then two layers were obtained. In extracting, each organic solvent sodium sulfate anhydrous was added and filtered. Afterward, the filtrate was evaporated at no $>50^{\circ} \mathrm{C}$ and then the residue was dissolved in $2 \mathrm{~mL}$ of methanol, then divided into three test tubes $[11,12]$.

The extract in the first tube was boiled in water and added a Liebermann-Burchard reagent and then a blue or green color was occurred that indicating the presence of glycosides $[11,12]$.

The third tube of sample was boiled in water, then cooled and filtered. After that, added a lot of Fehling A and Fehling B solution and heated, then a red brick precipitate was formed that exhibit the presence of reducing sugar $[11,12]$.

The extract in the second tube was evaporated over a water bath, then added $2 \mathrm{~mL}$ of water and 5 drops of Molisch reagent. Next, added $2 \mathrm{~mL}$ of concentrated sulfuric acid, then a purple ring was formed at the fluid boundary that indicating a sugar bond $[11,12]$.

\section{Identification of saponins}

The ethanol extract $(500 \mathrm{mg}$ ) was put into a test tube. After that, $10 \mathrm{~mL}$ of hot water was added, then cooled and shaked with vigorously for $10 \mathrm{~s}$. If the compound was examined in the form of a liquid preparation, diluted $1 \mathrm{~mL}$ of that liquid preparation with $10 \mathrm{~mL}$ of distilled water and shaked vigorously for $10 \mathrm{~min}$. A positive result was exhibited with a constant froth for no $<10 \mathrm{~min}$, as high as $1 \mathrm{~cm}$ to $10 \mathrm{~cm}$, then by addition one drop of $\mathrm{HCl} 2 \mathrm{~N}$; the froth was not disappeared $[11,12]$.

\section{Identification of tannins}

The ethanol extract $(500 \mathrm{mg}$ ) was extracted with $10 \mathrm{~mL}$ of distilled water for $15 \mathrm{~min}$. Then filtered, the filtrates were diluted with distilled water until they were almost colorless. Taken $2 \mathrm{~mL}$ of filtrate and then added two drops of $10 \% \mathrm{FeCl}_{3}$ solution. Note the color that occurs, blue or green indicates tannin, blue indicates two hydroxy groups in the aromatic ring of tannin $[11,12]$.

\section{Identification of steroids and terpenoids}

The ethanol extract $(1 \mathrm{~g})$ was added with ether or n-hexane, let stand for $2 \mathrm{~h}$, then filtered. Next, the filtrate was evaporated. The result of extraction was added anhydride acetic acid and then pressed concentrated sulfuric acid (Liebermann-Burchard reagent). Occurrence of red or red or turn blue-green indicates a triterpenoids and steroids $[11,12]$.

\section{Test of swimming endurance}

Swimming endurance test was carried out using the natatory exhaustion method [13], where all test animals were trained to swim 3 times in 1 week. On the past day, swimming resistance was measured to show signs of fatigue, i.e. head sinking for 4-5 s, recorded as swimming time 1 . Test animals were rested for $30 \mathrm{~min}$. Furthermore, the experimental animals were divided into eight groups with each group having five animals. The first group was given $0.5 \% \mathrm{Na} \mathrm{CMC}$ as a negative control, the second group was given caffeine $0.26 \mathrm{mg}$ as a positive control, and the other group was given EEBL $5 \%, 10 \%, 20 \%$, beetroots $5 \%, 10 \%$, and $20 \%$. Leave it for 30 minutes and then test the resistance of the animal swimming pool in the same way, the time taken is recorded as swimming time 2. Data on the difference in swimming times 1 and 2 are recorded to see the effect of activity from the sample given to the test animals [14].

\section{RESULTS AND DISCUSSION}

\section{Phytochemical screening}

The results of phytochemical screening from ethanol extract of binahong (A. cordifolia) leaves and beetroots (B. vulgaris L.) displayed in Table 1 .

Identification of EEBL and beetroots showed that contains bioactive compounds, namely alkaloids, glycosides, flavonoids, saponins, tannins, and anthraquinone glycosides. Steroids were only found in binahong leaves, and cyanogenic glycosides were only found in beetroot extract.

A previous study described that the phytochemical screening of ethanol extract from A. cordifolia stem contains polyphenol, flavonoids, and saponins [15]. The other reports have shown that EEBL contain secondary metabolites, namely phenolic, flavonoids, alkaloids, and saponins [16]. In another study of $B$. vulgaris showed wide range of activity by betaine and polyphenol compounds contained. The content possessed by $B$. vulgaris can reduce mortality due to complications from various diseases [17]. Besides, the phytochemical screening of beetroot extracts shows the presence of flavonoids, saponins, sterols, and triterpenes [18]. The study by Maraie et al. demonstrated that the preliminary phytochemical evaluation of fresh and dried leaves of $B$. vulgaris had shown the presence of various bioactive compounds, namely glycosides, saponins, flavonoids, phenolic compounds, and tannins [19].

\section{Swimming endurance}

The results of the swimming endurance test animals in each group are displayed in Table 2.

The group that gave almost the same activity as caffeine was seen in the EEBL group of $10 \%$ and $20 \%$, while the activity provided by beetroots was not significant compared to binahong extract. It has been reported that A. cordifolia leaf extract of 90 $\mathrm{mg} / \mathrm{head}$ was increased the highly lymphocyte of guinea pig (Cavia cobaya) that proved the process of wound healing and endurance increases [20]. According to the previous report, the extract of binahong leaves was able to increase vitality and endurance [21]. The previous study has reported that 8-day supplementation with beetroot juice with chokeberry addition increases the physical tolerance in swimmers in both repeated maximal sprints and endurance swims in female swimmers [22]. It has been know that alkaloid compounds are a group of natural ingredients which show very broad biological activity, this compound was used as a pain reliever, stimulant, and also as an antimicrobial. The mechanism by forming competitive barriers to microbial protein adhesion to the polysaccharide receptor [23].

Table 1: Phytochemical screening result from ethanol extract

\begin{tabular}{lll}
\hline Bioactive compounds & Binahong leaves & Beetroots \\
\hline Alkaloids & + & + \\
Glycosides & + & + \\
Flavonoids & + & + \\
Steroids & + & - \\
Tannins & + & + \\
Saponins & + & + \\
Anthraquinone glycosides & + & + \\
Cyanogenic glycosides & - & + \\
\hline
\end{tabular}


Table 2: Swimming endurance results from ethanol extract

\begin{tabular}{lllll}
\hline Groups & \multicolumn{2}{l}{ Swimming time (minutes) } & & p \\
\cline { 2 - 4 } & $\mathbf{n}$ & Before & After & Difference \\
\hline Negative control & 5 & $21.136 \pm 0.745$ & $22.598 \pm 0.797$ & 1.462 \\
Positive control & 5 & $21.648 \pm 0.438$ & $55.088 \pm 1.707$ & 33.440 \\
EEBL 5\% & 5 & $21.062 \pm 0.557$ & $39.550 \pm 3.830$ & 18.488 \\
EEBL 10\% & 5 & $21.562 \pm 0.714$ & $50.704 \pm 10.340$ & 29.142 \\
EEBL 20\% & 5 & $21.998 \pm 0.810$ & $58.390 \pm 0.964$ & 36.392 \\
EEBR 5\% & 5 & $21.666 \pm 0.606$ & $30.814 \pm 1.368$ & $0.0001^{*}$ \\
EEBR 10\% & 5 & $21.436 \pm 0.789$ & $35.782 \pm 0.622$ & $0.003^{*}$ \\
EEBR 20\% & 5 & $21.586 \pm 1.106$ & $41.052 \pm 0.861$ & 14.346 \\
\hline
\end{tabular}

EEBL: Ethanol extract of binahong leaves, EEBR: Ethanol extract of beetroots

\section{CONCLUSION}

Binahong leaves and beetroots have almost the same bioactive content except in the steroid content. The binahong leaves increase swimming endurance activity higher than the beetroots.

\section{AUTHORS' CONTRIBUTIONS}

Both authors have contributed to research ideas and designs. Masnia wrote the manuscript with support from Manurung.

\section{CONFLICTS OF INTEREST}

All authors have none to declare.

\section{REFERENCES}

1. Vivian SG, Lawson BE, Turnbull I, Downey PO. Review: The biology of Australian weeds. Anredera cordifolia (Ten.) steenins. Plant Protect Q 2007;22 Suppl 1:2-10.

2. Laksmitawati DR, Widyastuti A, Karami N, Afifah E, Davidson Rihibiha D, Nufus H, et al. Anti-inflammatory effects of Anredera cordifolia and Piper crocatum extracts on lipopolysaccharide-stimulated macrophage cell line. Bangladesh J Pharmacol 2017;12 Suppl 1:35-40.

3. Nazliniwaty N, Suryanto S, Damanik DD. The utilization of binahong (Anredera cordifolia (Ten.) steenins) leaf as an anti-aging. Asian J Pharm Clin Res 2018;11 Suppl 1:87-9.

4. Garmana AN, Sukandar EY, Fidrianny I. Antihypertension study of Anredera cordifolia (Ten.) V. steenins extract and its fractions in rats through dexamethasone induction and nitric oxide release. Asian J Pharm Clin Res 2018;11 Suppl 1:278-82.

5. Leliqia NP, Sukandar EY, Fidrianny I. Antibacterial activities of Anredera cordifolia (Ten.) V. steenins leaves extracts and fractions. Asian J Pharm Clin Res 2017;10 Suppl 12:175-8.

6. Sukandar EY, Safitri D, Aini NN. The study of ethanol extract of binahong leaves (Anredera cordifolia (Ten.) V. steenins) and mulberry leaves (Morus nigra L.) in combination on hyperlipidemic induced rats. Asian J Pharm Clin Res 2016;9 Suppl 6:288-92.

7. Sutrisno E, Adnyana IK, Sukandar EY, Fidrianny I, Aligita W. Antiinflammatory study of Anredera cordifolia leaves Centella asiatica herbs and its combantions using human red blood cell-membrane stabilization method. Asian J Pharm Clin Res 2016;9 Suppl 5:78-80.

8. Biondo PB, Boeing JS, Barizão EO, de Souza NE, Matsushita M, de Oliveira CC, et al. Evaluation of beetroot (Beta vulgaris L.) leaves during its developmental stages: A chemical composition study. Food Sci Technol (Campinas) 2014;34 Suppl 1:94-101.
9. El-Gengaihi SE, Hamed MA, Aboubaker DH, Mossa AT. Flavonoids from sugar beet leaves as hepatoprotective agent. Int J Pharm Pharm Sci 2016;8 Suppl 4:281-6.

10. Hamdiken M, Kechird Z. Chard (Beta vulgaris Var. Cicla) extract modulates zinc status, glucose level and antioxydant values in diabetic rats fed zinc deficiency diet. Int $\mathrm{J}$ Pharm Pharm Sci 2017;9 Suppl 10:297-304

11. Health Department of Republic of Indonesia. Materia Medika Indonesia. Vol. 5. Jakarta: Directorate General Supervision of Drugs and Food (Dirjen POM); 1989.

12. Farnsworth NR. Biological and phytochemical screening of plants. J Pharm Sci 1966;55:225-76.

13. Turner RA. Screening Methods in pharmacology. Vol. 1. New York: Academic Press; 1965.

14. Yulianita, Kardono BS, Simanjuntak P. Stimulantia effectiveness of extract green tea, red ginger and centella lozenges. J Young Pharm 2017;9 Suppl 1:70-2.

15. Kumalasari E, Sulistyani N. Antifungal activity of ethanol extract of binahong stem (Anredera cordifolia (Tenore) Steen) against Candida albicans and phytochemical screening. Univ Ahmad Dahlan 2011;1:51-62.

16. Basyuni M, Ginting PY, Lesmana I. Phytochemical analysis of binahong (Anredera cordifolia) leaves extract to inhibit in vitro growth of Aeromonas hydrophila. Am Inst Phys 2017;020072:1-5.

17. Váli L, Stefanovits-Bányai E, Szentmihályi K, Fébel H, Sárdi E, Lugasi A, et al. Liver-protecting effects of table beet (Beta vulgaris var. Rubra) during ischemia-reperfusion. Nutrition 2007;23:172-8.

18. Onkar PR, Powar PV, Sharma PH, Avari JG. Evaluation of phytochemical and pharmacological activity of beetroot extracts (Beta vulgaris). Biochem Pharmacol 2013;2 Suppl 4:145.

19. Maraie NK, Abdul-Jalil TZ, Alhamdany AT, Janabi HA. Phytochemical study of the Iraqi Beta vulgaris leaves and its clinical applications for the treatment of different dermatological diseases. World J Pharm Pharm Sci 2014;3 Suppl 8:5-19.

20. Wijayanti D, Setiatin ET, Kurnianto E. Leucocyte profile and offspring production of guinea pig (Cavia cobaya) given Anredera cordifolia leaf extract. J Indonesian Trop Anim Agric 2018;43 Suppl 1:19-25.

21. Manoi. Binahong as a medicine. Plantation Research and Development Center, Yogyakarta, Warta: Industrial Research and Development Warta; 2009.

22. Pospieszna B, Wochna K, Jerszynski D, Goscinna K, Czapski J. Ergogenic effects of dietary nitrates in female swimmers. Trends Sport Sci 2016;1 Suppl 23:13-20.

23. Heinrich M, Barnes J, Gibbons S, Williamson EM. Fundamentals of Pharmacognosy and Phytotherapy. $2^{\text {nd }}$ ed. Amsterdam: Elsevier; 2012. 